\title{
Cuerpo e imagen en la instalación Paracaidista Av. Revolución 1608 bis de Héctor Zamora
}

\section{Body and Image in Héctor Zamora's Installation. Paracaidista Av. Revolu- ción 1608 bis}

Artículo recibido el 30 de octubre de 20I6; devuelto para revisión el 7 de febrero de 20I7; aceptado el I3 de septiembre de 20I7, http://dx.doi.org/IO.2220I/iie. I8703062e.20I8.II2.2624

Eduardo Maldonado Universidad Nacional Autónoma de México-Facultad de Filosofía y

Villalobos Letras, México. maculadaconceptualizacion@gmail.com

Líneas de investigación Análisis de las estrategias visuales de las intervenciones artísticas en el espacio público en comparación con las estrategias de la publicidad exterior y con los mecanismos de percepción urbana.

Lines of research Analysis of the visual strategies of artistic interventions in the public spaces in comparison with the strategies of outdoor advertising and with the mechanisms of urban perception.

Publicaciones más relevantes "La superficie urbana de una galería expandida. Anotaciones sobre el proyecto Sonora 128 de la galería Kurimanzutto", .925 Artes y Diseño, en http://revista925taxco.fad.unam.mx/index.php/2017/o2/23/lasuperficie-urbana-de-una-galeria-expandida/.

Resumen Este artículo hace una interpretación de la instalación Paracaidista $A v$. Revolución I608 bis, del artista mexicano Héctor Zamora, realizada al exterior del edificio del Museo de Arte Carrillo Gil en 2004, con su contexto urbano como punto de partida. En éste se señala el contraste entre imagen y cuerpo mediante la conjugación entre el emplazamiento de la fachada del edificio y el uso de la instalación como vivienda; se considera la fachada como una zona destinada principalmente a la imagen, de manera que el habitar se activó como una interrupción visual al condicionamiento perceptivo de la urbe, que encuentra este tipo de superficies ocupadas por la publicidad. Se propone así que la intervención realiza una interferencia por medio del cuerpo que habita, y señala un vacío vertical al que no es capaz de sustraerse como imagen ni como ficción.

Palabras clave Arte contemporáneo en la Ciudad de México; intervenciones artísticas; espacio público; visualidad urbana; fachadas arquitectónicas. 
Abstract The article delivers an interpretation of the installation Paracaidista Av. Revolución I608 bis, by Mexican artist Héctor Zamora, built on the façade of the Carrillo Gil Art Museum in 2004, using its urban setting as a reference point. The contrast between image and body is emphasized by the conjunction of the façade's placement and the use of the installation as a dwelling. The façade is understood as an area destined primarily for the image, while the dwelling was activated as a visual interruption of the perceptive conditioning of the city, which offers surfaces of this sort for publicity uses. The article suggests that the intervention represents an interference by means of the body that dwells, revealing a vertical emptiness which cannot be escaped, whether as image or as fiction.

Keywords Contemporary art in Mexico City; art intervention; public space; urban visuality; architectural façades 
DOI: http://dx.doi.org/10.22201/iie.18703062e.2018.112.2624

\author{
EDUARDO MALDONADO VILLALOBOS \\ UNIVERSIDAD NACIONAL AUTÓNOMA DE MÉXICO \\ FACULTAD DE FILOSOFÍA Y LETRAS \\ MÉXICO
}

\title{
Cuerpo e imagen en la instalación Paracaidista Av. Revolución I608 bis de Héctor Zamora
}

a intervención del artista mexicano Héctor Zamora (1974) llamada Paracaidista Av. Revolución I608 bis de 2004 en el Museo de Arte Carrillo Gil surgió de un planteamiento curatorial en el que se buscaba establecer una presencia institucional en el exterior urbano por medio de las estrategias del arte contemporáneo para atraer nuevos públicos. Así, la fachada del edificio de dicho museo fue la superficie sobre la cual se construyó un espacio habitable con materiales de bajo costo. La estructura resultante adquirió un aspecto marginal que, aunado a su sorpresiva ubicación, interrumpió la visualidad del edificio modernista/brutalista del Carrillo Gil y la de su contexto urbano, la zona privilegiada de San Ángel, situada al sur de la Ciudad de México. El mismo Zamora ocupó la instalación como su propia vivienda durante los tres meses que duraría la exhibición. ${ }^{\mathrm{I}}$ Paracaidista se mostró, finalmente, como

I. Héctor Zamora estudió Diseño de la Comunicación Visual en la Universidad Autónoma de México; cursó el Taller de Semiótica impartido por Ada Dewes, a partir del cual comenzó a interesarse por la experimentación con las formas orgánicas desde la teoría del diseño; realizó estudios de geometría estructural en la Facultad de Arquitectura de la Universidad Nacional Autónoma de México, así como diversos proyectos de estructuras ligeras; trabajó como diseñador gráfico en el Museo de Arte Carrillo Gil durante la dirección de Osvaldo Sánchez (1998-200I). El paso del diseño gráfico a las estructuras arquitectónicas y, finalmente, a la reflexión artística tuvo como común denominador el análisis de matrices geométricas en las formas de la naturaleza para recrearlas en nuevas configuraciones. Para el nombre de esta instalación, Zamora toma primero la palabra Paracaidista del mote con el que se identifica coloquialmente a grupos marginados que 
a)

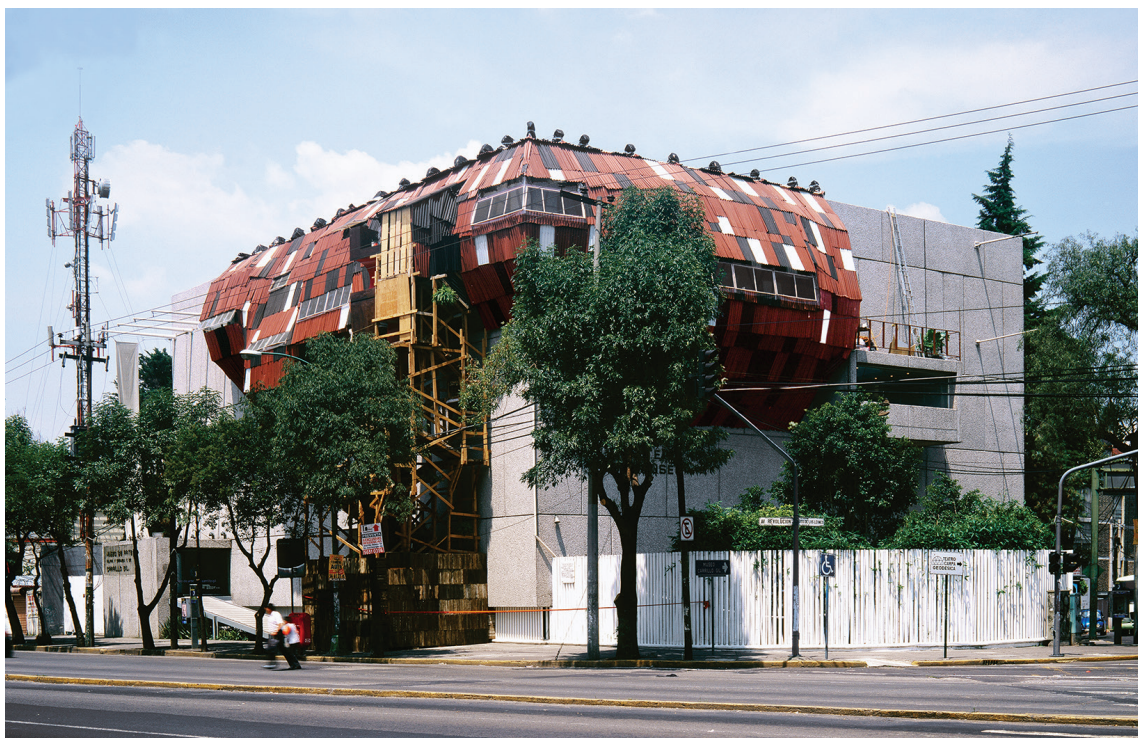

Ia-c) Héctor Zamora, Paracaidista Av. Revolución I608 bis, exterior, Ciudad de México. Foto: Fernando Medellín, 2004.

una especie de desconcertante marca urbana, y se convirtió en un punto de referencia en el arte de exteriores producido en México (fig. I).

La relación de dependencia de esta casa y de su habitante con el edificio y la institución museística fue la pauta para la línea curatorial que se basó en la noción de parásito, propuesta por Zamora y por el curador Gonzalo Ortega. Con esto definían el sitio específico de la instalación como el de las instituciones tanto culturales como gubernamentales, en el que destacaba un enfoque de crítica institucional. No obstante, para el propio Zamora, Paracaidista fue, antes que cualquier otra cosa, su casa; de manera que la estructura montada giraba en torno al cuerpo de su habitante (fig. 2$).^{2}$

ocupan de manera irregular un terreno o un inmueble con la finalidad de establecer allí su propia vivienda. El resto del nombre se refiere a la ubicación del Carrillo Gil acompañada con el adjetivo bis con el que irónicamente se autodesignaba como un domicilio yuxtapuesto.

2. Héctor Zamora, en entrevista por Skype el 29 de noviembre de 20I3. El alcance de la obra se reflejó en los múltiples textos que se publicaron durante el tiempo en que estuvo montada (tanto para la difusión en periódicos de circulación nacional, como dentro de la crítica especializada). En la mayoría de éstos se reflexionaba sobre la noción del parásito, y se buscaba definir lo que pudiera ser, por un lado, el organismo huésped y, por otro, el organismo invasor. 
DOI: http://dx.doi.org/10.22201/iie.18703062e.2018.112.2624

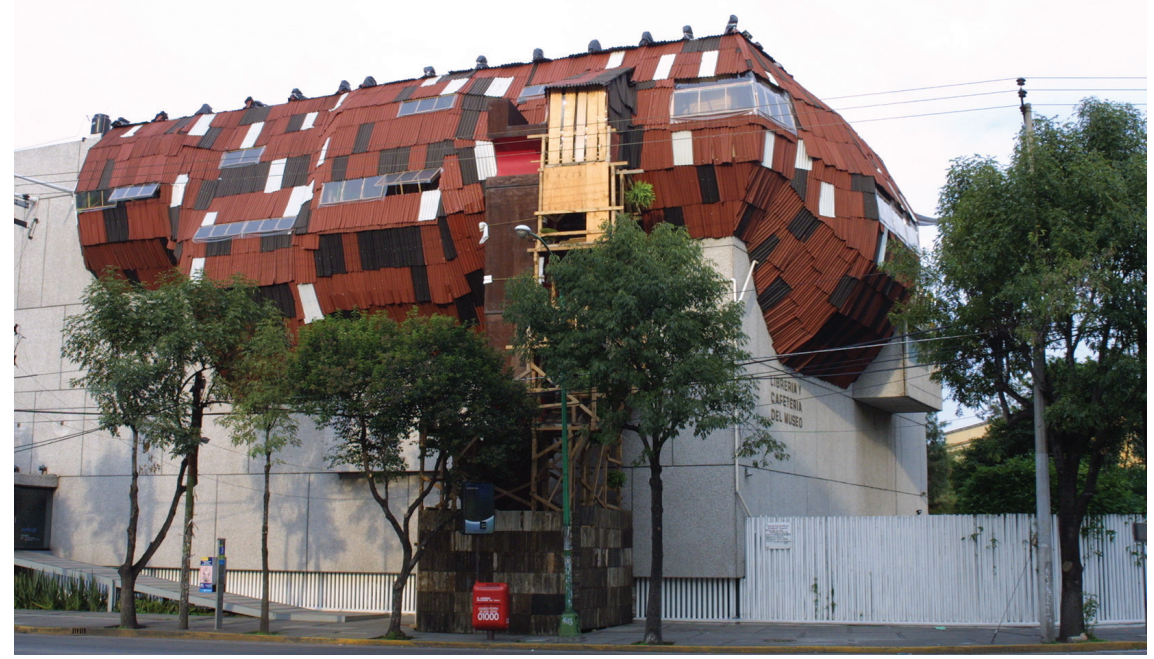

b)

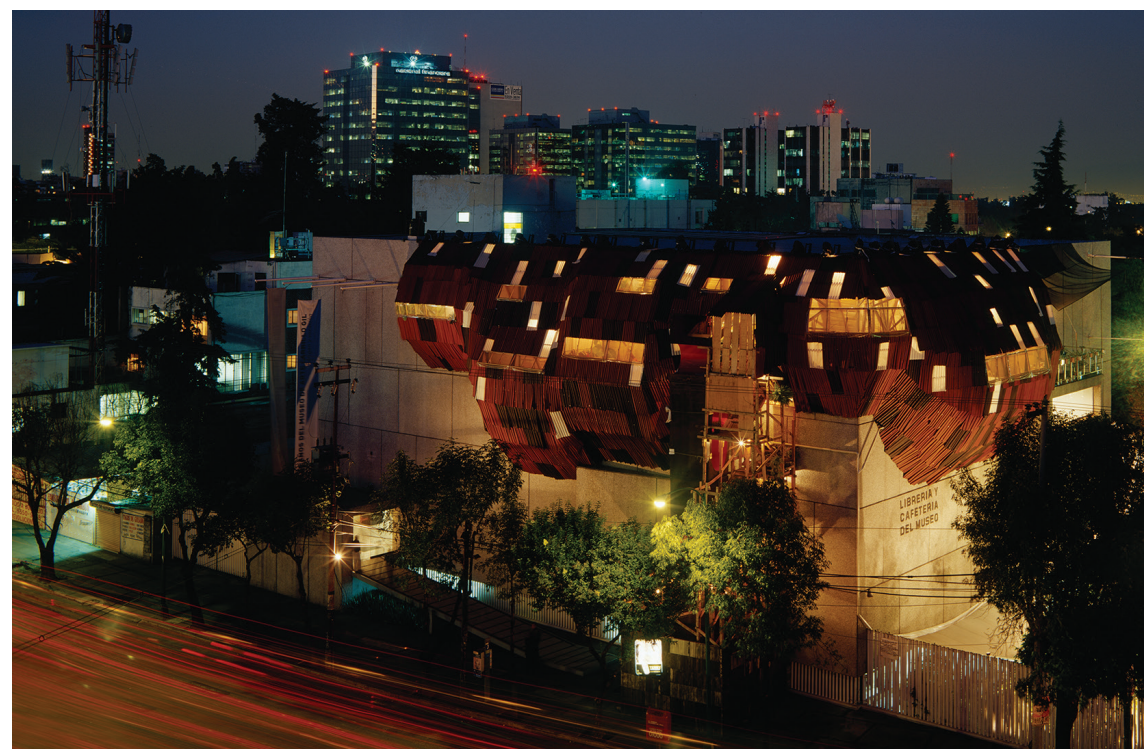

c) 
Aún después del desmontaje, la obra continuó generando discusión. En 2005, a sólo algunos meses después de la desinstalación, la documentación del proyecto formó parte de dos importantes muestras en las que México contaría con una pujante visualización internacional. La primera fue "Eco: arte contemporáneo mexicano", curada por Kevin Power y Osvaldo Sánchez en el Museo Nacional Centro de Arte Reina Sofía de Madrid (como parte de la Feria Internacional de Arte Contemporáneo ARCO 05). La segunda muestra fue "Farsites", exposición curada por Adriano Pedrosa dentro del marco de "inSite 05" de Tijuana/San Diego. ${ }^{3}$

En el catálogo de la exposición de ARCo, el crítico Cuauhtémoc Medina utiliza Paracaidista como punta de lanza para esgrimir una ruta interpretativa sobre el arte producido desde la década de los noventa. Al aprovechar el contexto internacional de la muestra, traza una discusión en la que las obras revisadas develaban una actitud crítica hacia los efectos modernizadores de la globalización. ${ }^{4}$ Con nociones como la "estética del modernizado" y la "estética de la sobrevivencia" configuraba una identidad de la crisis en la que Paracaidista encajaba perfectamente por su directa referencia a un entramado urbano del subdesarrollo.

Por su parte, Pedrosa basa el discurso curatorial de "Farsite" en una noción de falla localizada en las ciudades latinoamericanas. Las obras reunidas tenían como común denominador la referencia al fracaso de la aplicación del proyecto moderno con sus consecuentes crisis públicas y urbanas. El acento en el urbanismo de lo informal era también una exploración de una "estética de

3. A principios del siglo xxi se realizaron una serie de exhibiciones en las que la producción artística de México ingresaba a los circuitos internacionales: en 200I, Magalí Arriola organizó la exposición "Coartadas" en el Centro Cultural de México en París; ese mismo año la revista canadiense Parachute dedica un número a la producción cultural en México, e invita a Cuauhtémoc Medina como editor; en 2002, Arriola cura Zebra Crossing en la Casa de las Culturas del Mundo en Berlín dentro del festival MexArtes, donde a su vez James Oles cura "Superficies coloreadas", asimismo en el KunstWerke de Berlín, como previamente en el P.S.I, de Nueva York, Klaus Biesenbach presenta "Mexico City: An Exhibition About the Exchange Rate of Bodies and Values". En 2003 Teresa Macrì organiza "Mexico Attacks" en Italia. En 2004, Gilberto Vicario organiza "Made in Mexico" en el Institute of Contemporary Art de Boston; y en 2005, México es el país invitado en la Feria ARCo de Madrid.

4. Véase Cuauhtémoc Medina, "Notas para una estética del modernizado", en Eco, arte contemporáneo mexicano (Madrid: Museo Nacional Centro de Arte Reina Sofía, 2005), I3-I8. Algunos artistas que integraron la muestra fueron Teresa Margolles, Eduardo Abaroa, Ińaki Bonillas, Mariana Botey, Miguel Calderón, José Dávila, Thomas Glassford, Enrique Ježik y Francis Alÿs. 
DOI: http://dx.doi.org/10.22201/iie.18703062e.2018.112.2624
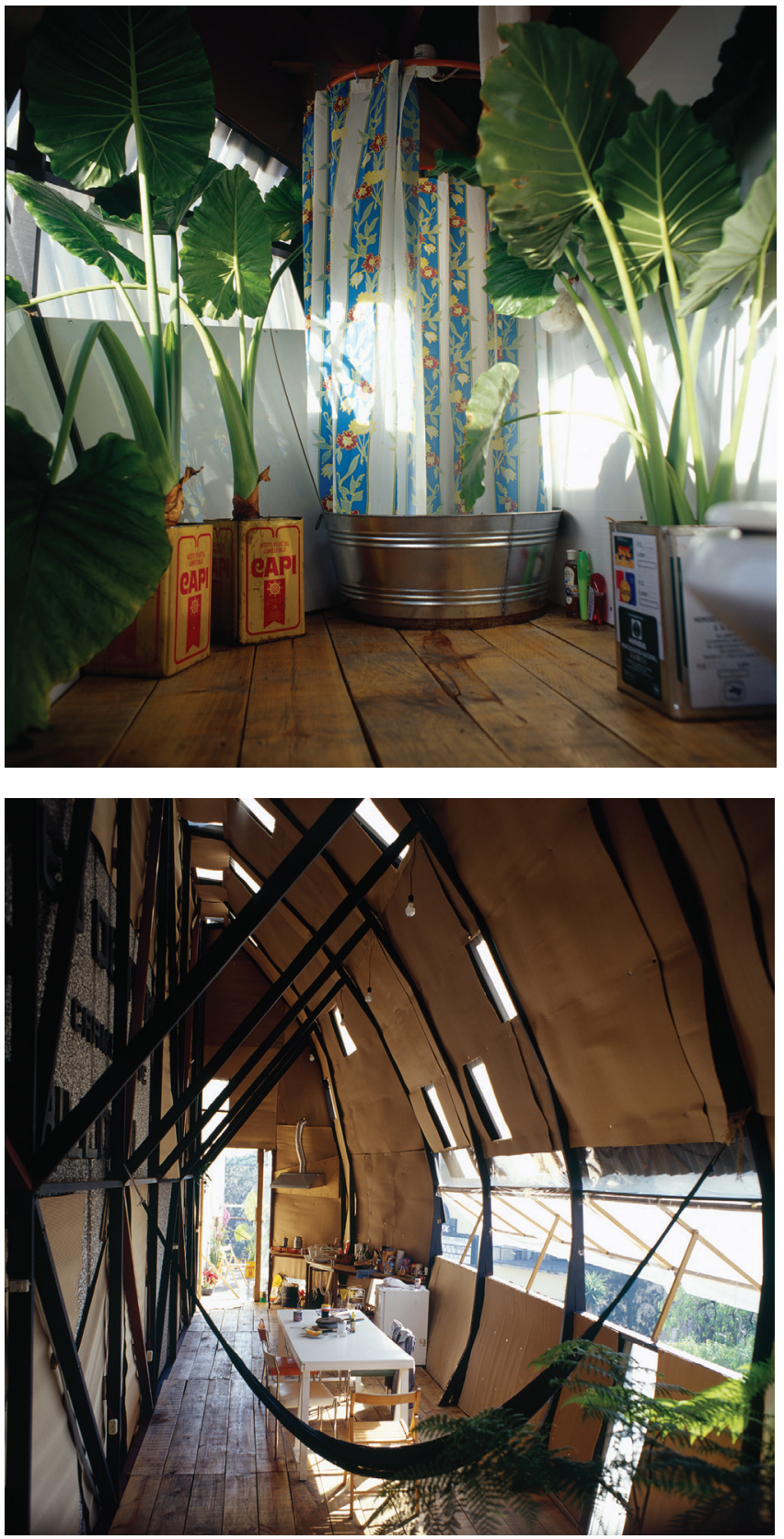

2a y b) Héctor Zamora, Paracaidista Av. Revolución I608 bis, 2004, interior, Ciudad de México. Foto: Fernando Medellín, 2004. 
la sobrevivencia" latinoamericana.5 Paracaidista, en este sentido, se mimetizaba con una "estética de las favelas" al mismo tiempo que se contrastaba con el exterior del museo. La fragilidad, el riesgo y la incertidumbre se proyectaban como interferencias a "tamaño natural"; cualidad que podía ir, en opinión de Pedrosa, más allá de la representación y de la investigación formal. ${ }^{6}$

Así, Paracaidista se caracterizó principalmente, como apuntó Reyes Palma, por realizar una especie de "extracción de sentido" de los sectores urbanos marginales; ${ }^{7}$ es decir, en estas interpretaciones se le valoraba por su capacidad de observación y reinterpretación de un problema ajeno al sistema del arte. El reto inicial, señalado por Zamora, era el de colocar una forma orgánica sobre un entorno inusual que, al tratarse de la verticalidad de la fachada, se tornaba adverso. La referencia a la marginalidad urbana surgió posteriormente al relacionar su habitar con las estrategias de supervivencia de los habitantes de las zonas periféricas de la ciudad. ${ }^{8} \mathrm{Al}$ referirse a los cinturones de miseria de la ciudad, Paracaidista entró en un juego de visibilidades en el que los hacía perceptibles en medio de una zona urbana privilegiada. Este efecto se alcanzó por el

5. La muestra incluía trabajos de Francis Alÿs, Rubens Mano, Marjetica Potrc, Ana María Tavares, Sean Snyder, entre otros. Adriano Pedrosa, "Sitios distantes", en Sitios distantes. Crisis urbanas y sintomas domésticos en el arte contemporáneo (San Diego Museum of Art / Centro Cultural Tijuana, 2005).

6. Pedrosa, "Héctor Zamora", Artforum, núm. 7 (marzo, 2005): 245.

7. Francisco Reyes Palma, "Héctor Zamora, el arte como síntoma”, Curare, núm. 25 (enerojunio, 2005): II-I2.

8. En instalaciones anteriores se puede percibir su trabajo con las formas orgánicas. En 2000 realiza la intervención $a=360^{\circ} \mathrm{r} / R$ al interior de la escultura habitable de la Torre de los vientos bajo un programa de arte in situ coordinado por Pedro Reyes. Con una tela elástica se cubría el espacio interior de la torre, y se transformaba su aspecto original de formas grises y angulosas en un relieve suave, continuo y curvo. Se establecía una oposición entre la geometría áspera de la escultura con la delicadeza de la tela como un nuevo ambiente al cual el visitante podía ingresar. Posteriormente, en Pneu de 2003, realizado en la Galería Garash de la Ciudad de México, Zamora instaló un enorme tubo de plástico rojo lleno de aire que invadía los espacios del edificio de la galería. El largo volumen recorría desde la entrada principal, por toda la planta baja, hasta salir por la parte posterior del edificio y subir, por detrás, tres pisos y regresar por la azotea hasta descender por la fachada y regresar finalmente a la entrada. De nuevo aparecía un contraste entre una forma orgánica frágil y una estructura arquitectónica rígida, que tenía en esta ocasión una presencia con el exterior urbano al ser visible desde la calle. Tanto en $a=360^{\circ} r / R$ como en Pneu el volumen que alteraba la edificación huésped implicaba una relación perceptiva con el cuerpo del visitante. En Paracaidista se reemplazaba tanto la tela de uno como el plástico del otro por lámina acanalada como material visible predominante. 
lugar ocupado, caracterizado por contar, precisamente, con una amplia visibilidad: la superficie de la fachada. Con este emplazamiento, la ciudad a la que también se apelaba era la que se exhibe mientras sus superficies, las cuales suelen estar ocupadas por imágenes publicitarias que recubren el espacio urbano, inciden en los imaginarios sociales. Al habitar su propia construcción, se generó un efecto de realidad dado por la presencia de un cuerpo, como un hecho que hacía interferencia en las superficies ocupadas por la imagen de las ficciones mercantiles.

De esta manera, al estar Paracaidista montado sobre una superficie urbana, se problematizaba una relación entre realidad y ficción que no fue lo suficientemente abordada en las reflexiones de su momento. Al centrarse los análisis sobre todo en la idea de la extracción de sentido y la estética de la supervivencia, se dejaba de lado el cómo se lograba hacer visible estas operaciones. Las relaciones entre cuerpo-habitar-realidad/imagen-verticalidad-ficción son las nociones que nos pueden guiar para hacer una nueva revisión sobre esta propuesta, en la cual el arte busca relacionarse con un exterior urbano.

Por tanto, se analiza la instalación con base en la siguiente premisa: al funcionar como una vivienda emplazada sobre la verticalidad de una superficie urbana, la instalación colocaba la realidad de un cuerpo que habita dentro de las apariencias de la imagen, y colapsaba ambas dimensiones. Así, Paracaidista señala un cruce entre las apariencias del cuerpo, al asumir sus comportamientos cotidianos en la ciudad, con las apariencias de los medios que predominan en la urbe. ${ }^{9}$

9. Como se verá más adelante, a Paracaidista también se le criticó por "aparentar" una situación de pobreza y faltar a una idea de verdad. El colapso que se suscita en Paracaidista no ocurre únicamente con las apariencias tomadas sólo en este sentido platónico, sino, como se verá a lo largo del artículo, en el sentido en el que se busca detonar, precisamente, las posibilidades de esta propiedad de la imagen. Para Hans Belting, las apariencias de la imagen están relacionadas con tres evocaciones: la imagen como la presencia de una ausencia (que explica por medio del pensar la muerte del cuerpo), como manifestación de posibilidades tecnológicas (que puede entenderse como posibilidades del medio con independencia del cuerpo) y como derivación de una capacidad medial que potencializa la percepción de los sentidos del cuerpo (aludiendo a la posición de McLuhan). Al hablar de las tecnologías más recientes, Belting encuentra que las apariencias de la imagen funcionan como promesas de "la liberación de la referencia al mundo real". Éstas, dice, "no abren ningún acceso a un más allá de las imágenes en el que nuestros conceptos por fuerza resulten inválidos, sino que simplemente amplían el universo de las imágenes, que de todos modos se extiende más allá de nuestra propia experiencia corporal sin importar qué las haya motivado", en Hans Belting, Antropología de la imagen, trad. Gonzalo María Vélez Espinosa (Buenos Aires: 
Paracaidista funge entonces como presencia comunicativa en la urbe requerida por el propio museo, que condujo a la colocación de un habitar ante la mirada. Al no haberse configurado como una propuesta de arte público crítico, su percepción se basó en las sensaciones de asombro y temor que derivaron en la aceptación o rechazo por parte de los receptores. El emplazamiento de la fachada puede discutirse como un medio visual que genera un terrain vague vertical, evidenciado por la propia ausencia del espacio habitado emplazado en ella misma. En contraste se presenta un montaje proveniente del mundo publicitario llamado \#ScribeBillboard para destacar la manera en que el habitar como imagen actúa por medio de la superficie vertical y con el entorno urbano.

La noción de parásito, ampliamente discutida durante el tiempo en que estuvo montado Paracaidista, no se toma en cuenta, puesto que resulta relevante retomar lo que Zamora planteó como punto de partida: la construcción de su propia casa sobre una superficie vertical. El resultado de esto, junto con la necesidad de presencia exterior por parte del Carrillo Gil, la posterior desinstalación que dejaba nuevamente libre la fachada del edificio y la comparación con lo presentado como el \#ScribeBillboard, fueron las claves que detonaron la reflexión propuesta aquí. De alguna manera fue el \#ScribeBillboard el que, en el proceso de análisis, arrojó una nueva luz interpretativa, ya que hizo una definición y un aprovechamiento del potencial visual y comunicativo del habitar manifestado en Paracaidista.

\section{El habitar dispuesto a la mirada}

La ubicación para la instalación de Zamora surgió de un planteamiento de visualización del edificio del Carrillo Gil. En 2002 el equipo de curaduría buscó comisionar proyectos para la fachada con el objetivo de establecer una relación comunicativa entre las actividades de la institución y el exterior urbano. El curador Gonzalo Ortega buscaba que, mediante las estrategias del arte contemporáneo, se activara un potencial visual capaz de atraer nuevos públicos:

Katz Editores, 2007), IO2. En Paracaidista se estaría planteando una posible interjección entre una dimensión del cuerpo y una dimensión de la imagen dentro de una dimensión urbana. 
La intención era en aquel entonces lograr que el edificio fuera reconocido como un lugar destinado al arte contemporáneo. Esto pretendía justificarse meramente en el hecho de que para muchos habitantes de la ciudad el museo es inadvertido, así como en un interés legítimo por hacer más comprensibles los enunciados del arte contemporáneo para la gente con poca información al respecto. ${ }^{10}$

Implícitamente se consideraba que las capacidades de comunicación de la fachada arquitectónica estaban siendo rebasadas por una necesidad de diferenciación dentro del entramado urbano. ${ }^{\text {II }}$

Io. Gonzalo Ortega, "Paracaidista Av. Revolución I608 bis", Paracaidista. Av. Revolución I608 bis. Intervención de Héctor Zamora (Ciudad de México: Museo de Arte Carrillo Gil, 2007), i6.

II. El edificio del Carrillo Gil de 1958 de Augusto H. Álvarez, identificado con el funcionalismo internacional, lo remodeló su hijo homónimo en 1988, al seguir las premisas del entonces novedoso brutalismo arquitectónico. La remodelación consistió en el reemplazo de las predominantes ventanas y celosías en las fachadas por la actual cubierta de bloques de concreto prefabricado as found. La intención era reafirmar la función del edificio como museo y proyectar un renovado y vigente aspecto visual. Véase Jorge Reynoso, "Apuntes a una vocación", 30 años del Museo de Arte Carrillo Gil. Origen y vocación (Ciudad de México: Instituto Nacional de Bellas Artes-Consejo Nacional para la Cultura y las Artes, 2004). En 2002 se realizó, con el planteamiento de Gonzalo Ortega, la intervención de Gustavo Artigas, Emergency exit. La propuesta consistió en utilizar la rampa del acceso principal del museo por un motociclista, quien subiría hasta romper un muro falso para llegar al estacionamiento ubicado a un costado. La rampa característica del edificio era el elemento sobre el que recaía la atención; y la temporalidad como evento no dejó huella que sirviera para los fines iniciales de Ortega. La fachada sólo sirvió como telón de fondo. Después de Paracaidista, el programa de Ortega no tuvo continuidad a pesar de la visualidad alcanzada tanto para la institución como para la trayectoria de Zamora. No obstante se marcó un precedente en la realización de proyectos posteriores que buscaban también una proyección del arte hacia la urbe desde el exterior del edificio. En 2006, Ramiro Chaves con Proyecto Canadá reubicó en la azotea del Carrillo Gil las letras gigantescas del anuncio luminoso "Canadá" que se encontraban instaladas a un costado de un edificio de la avenida Insurgentes de la Ciudad de México. Si bien, no apelaba a las potencialidades comunicativas del edificio, extrajo un elemento ampliamente visible de una fachada urbana para relocalizarlo. Proyecto para el Museo de Arte Álvar y Carmen T. de Carrillo Gil de Tercerunquinto de 2008 consistió en retirar las letras del nombre del edificio ubicadas en la fachada, para colocarlas en una sala interior. Este gesto permanecía casi invisible desde la mirada exterior. En ese mismo año, Levitación asistida de Fernando Ortega consistió en la colocación de una grúa de construcción a un costado del edificio para sostener un bebedero para colibríes, el cual era visible desde la ventana de una de las salas del museo. La monumental grúa no se diferenciaba del entorno en tanto que su presencia se asocia directamente a un paulatino cambio constructivo de la ciudad. Su significación era perceptible al encontrar la fragilidad del bebedero que sostenía. En 20II, Panteón de José Carlos Martinat consistió en extraer la pintura 
El resultado fue una instalación que interrumpía la visualidad del edificio y la del contexto urbano. ${ }^{\text {I2 }}$ Su base constructiva estaba formada por un esqueleto metálico convexo sostenido por medio de grúas fijadas en el techo del edificio. Con una cubierta de láminas asfálticas acanaladas se confería la apariencia de construcción marginal. La retícula quebrada y escamosa color rojo quemado, negro opaco y blanco translúcido contrastaba con la superficie plana y gris de concreto martelinado de la fachada del Carrillo Gil.

Desde el exterior se percibían elementos que indicaban que se trataba de un espacio habitado: las ventanas abiertas, hechas con bastidores de madera forrados con hule transparente, la luz interior encendida en las noches, y las plantas que se asomaban desde el andamio de acceso y desde la parte superior de la ventana saliente del edificio, que fue aprovechada como terraza.

El andamio de acceso, al estar formado como escalinata hecha con planos inclinados de madera y chaperas clavadas como peldaños, contrastaba con la escultura de Alejandro Prieto (Ciudad de México, I924-1996), mostraba fragilidad, pero también dependencia al tener que amarrarse con lazos para contar con mayor firmeza. ${ }^{13}$ La asignación funcional de los espacios interiores era la habitual de un departamento: estancia-comedor, dos recámaras, baño y pasillos. No obstante, su distribución estaba replegada a la verticalidad. La apropiación de la fachada hacía de su exterioridad una pared interior. Zamora identificó la instalación como una construcción parasitaria por su dependencia estructural y por la extracción de los servicios de agua y luz del museo. ${ }^{\mathrm{I}}$

de una barda que anunciaba un concierto del grupo musical Panteón Rococó, para colocarla en una manta que superpuso en la fachada del Carrillo Gil.

I2. El Carrillo Gil se encuentra en el cruce conflictivo y muy transitado de las avenidas Revolución y Altavista en la zona de San Ángel. En los alrededores se encuentran centros comerciales, un mercado tradicional de flores, calles empedradas, bares, restaurantes exclusivos, centros nocturnos, casonas históricas, centros culturales, parques y residencias pertenecientes a clases acomodadas. Se trata de una zona heterogénea con una intensa actividad comercial y turística. En registros tomados en video desde el interior de la instalación se observa la mirada curiosa de los automovilistas que debían detenerse antes de atravesar el cruce por el semáforo en alto.

13. Esta relación fue señalada por la crítica como una diferencia de estrategias entre un arte moderno que buscaba una presencia urbana sólida y permanente y un arte contemporáneo que llega a resultados transitorios. Véase Medina, "Arquitectura post-apocalíptica”, Reforma, Sección C Cultura, México, jueves 26 de agosto de 2004, 4; y Reyes Palma, "Héctor Zamora, el arte como síntoma”, i5.

I4. Reyes Palma consideró que con Paracaidista el museo exhibía una imagen interior degradada debido al escaso interés de las políticas gubernamentales en cuanto a su apoyo a la cultura, de tal suerte que se desarrollaba una dependencia de la iniciativa privada para el desarrollo de proyectos 
La colocación de la estructura en la fachada estuvo acompańada por una exposición al interior del museo en la que se mostraban los formatos burocráticos, cartas a funcionarios y estudios técnicos como narrativa de las dificultades y tropiezos que tuvieron que superarse para llevar a cabo la instalación. ${ }^{\text {Is }}$ Así, la muestra se componía tanto de esta exposición como de visitas guiadas al interior de la instalación. El visitante podía entrar a un espacio privado donde con la mirada esperaba hallar alguna revelación al enigma de la identidad de su ocupante suscitado mediante la apariencia exterior.

Michel de Certeau plantea una relación idealizada entre cuerpo y casa en tanto espacio privado. La casa, dice, funciona como una protección que separa las presiones del "cuerpo social" del "cuerpo individual". Es un "habitar aparte" en donde el cuerpo dispone como mejor le parece de un "abrigo cerrado" sustraído de la mirada y de la "presencia del prójimo. [...] Este territorio privado hay que protegerlo de las miradas indiscretas, pues cada quien sabe que el menor alojamiento descubre la personalidad de su ocupante" ${ }^{16} \mathrm{El}$ giro de Paracaidista fue precisamente en el sentido opuesto porque existía la intención

artísticos (los recursos que financiaron el proyecto provinieron de la Fundación BBva Bancomer). Reyes Palma, "Héctor Zamora, el arte como síntoma". No obstante, para Zamora el parásito era el propio arte que aun puede crecer dentro del conjunto de instituciones debilitadas: "Las características del Carrillo Gil son idóneas, ya que es parte del aparato de cultura gubernamental. Su edificio se ubica en un nodo vial extremadamente caótico, y además atraviesa un momento difícil por su situación financiera e intelectual, ocasionada por la actualidad política cultural. Es por tanto un huésped ideal para el experimento, ya que como todo ser débil en la naturaleza es propenso a desarrollar una infección". Héctor Zamora, citado por Gonzalo Ortega, "Paracaidista Av. Revolución I608 bis", hoja de sala de la exposición, agosto de 2004-noviembre de 2004.

I5. Debido a que el edificio del Carrillo Gil es considerado inmueble con valor artístico y que la enmarcación de San Ángel tiene la designación de zona histórica, el proyecto fue clausurado por las autoridades locales apenas instalada una parte de la estructura inicial. Los problemas legales que se presentaron tenían que ver con la interpretación institucional y burocrática, tanto del Instituto Nacional de Bellas Artes (INBA), el Instituto Nacional de Antropología e Historia (INAH) y la Delegación Álvaro Obregón de la Ciudad de México, de la Ley Federal sobre Monumentos y Zonas Arqueológicos, Artísticos e Históricos, el Registro Público de Monumentos y Zonas Artísticos (a cargo del INBA) y el Registro Público de Monumentos y Zonas Arqueológicas e Históricos (controlado por el INAH). El proceso legal y burocrático que debió emprenderse para obtener los permisos necesarios de las diferentes instituciones gubernamentales se basó en demostrar a cabalidad la reversibilidad y temporalidad de la instalación. La garantía de estos elementos fue la condición necesaria para permear por cierto tiempo el control burocrático de la visualidad de la zona.

I6. Michel de Certeau, "Espacios privados", en La invención de lo cotidiano 2. Habitar, cocinar (Ciudad de México: Universidad Iberoamericana, 1999), I48. 
de exponer el interior hacia la mirada. El acuerdo con el museo (como cuerpo social) fue permitir la entrada a los visitantes (el prójimo), y el mismo Zamora (el cuerpo individual) era quien debía funcionar como guía. El objetivo de la instalación, tanto de su aspecto exterior como interior, fue desde el principio la mirada, a la que se le sustraía lo indiscreto de sus escudrińamientos. Las visitas guiadas que se ofrecían en Paracaidista permitían observar e interactuar con el espacio creado y con su ocupante.

En este sentido, la instalación, al estar expuesta fuera del museo y al abrirse a los visitantes, suscitó reflexiones en cuanto a su aportación o rechazo a las manifestaciones de un arte público contemporáneo.

\section{Del arte público al asombro y el temor}

Interesada en la manera en que los públicos de arte se sienten implicados tanto por las instituciones como por las obras mismas, Graciela Schmilchuk desestima la instalación Paracaidista como arte público y señala que no proponía prácticas simbólicas que llevaran a la construcción de ciudadanía. En su análisis distingue dos tipos de públicos que percibieron la propuesta, uno interesado en el arte, poseedor de herramientas suficientes de interpretación, y otro casual, el cual no contaba con marcos referenciales claros que guiaran la percepción y evitaran una sensación de vacío. El vacío, dice, se convierte en malestar "cuando el efecto de verdad falla y la incertidumbre se hace insoportable", lo que entorpece los procesos cognitivos que podrían activarse. ${ }^{17}$

Schmilchuk piensa la obra de Zamora en relación con el exterior del museo $y$, por tanto, con un espacio no demarcado por las convenciones artísticas. Así, la fachada del museo como exterior involucraba un enfoque distinto a las regulaciones del interior. En este exterior, Schmilchuk consideraba que la obra quedaba relegada a la indeterminación. Reconoció, no obstante, que la obra podía lograr la captación de nuevos públicos. Desde este punto de vista, Paracaidista fracasaba como arte público.

17. Graciela Schmilchuk, "Públicos, participación, desplazamientos", Curare, núm. 25 (enerojunio, 2005), III. Los marcos referenciales son para Schmilchuk la mediación que ocurre en el encuentro obra-espectador regulada por la curaduría, museografía, crítica y prensa, así como por espacios de difusión como bienales, galerías, colecciones y museos. 
En efecto, la instalación de Zamora no manifestaba una preocupación explícita por comprometer a un otro, fuera éste el público ajeno al campo del arte o los propios habitantes de las zonas marginales. La exhibición exterior que se ejercía a tamaño natural —o, si se quiere, de manera monumental — se ofrecía sin una certidumbre interpretativa y sin proponer un papel activo en el receptor que apelara a una asociación entre exterioridad y participación. Lo que hizo Zamora fue justamente lo contrario: una especie de privatización de la fachada para beneficio personal. ${ }^{18}$

En el esfuerzo por comprender el funcionamiento de la obra, Schmilchuk realizó una encuesta a transeúntes casuales, con el objeto de registrar la capacidad que tuvo para acercar a nuevos públicos y el impacto estético que produjo. Por su parte, en la puerta de acceso a la morada temporal, Zamora colocó un buzón en el cual recibió constantemente comentarios sobre la obra. ${ }^{19}$ En ambos casos, se trató de gestos en los que se intentaba asir el efecto producido por la indeterminación de una obra ampliamente expuesta sobre un público incierto. Las opiniones expresadas fueron tanto de atracción como de desaprobación. Sin embargo, fue en estas últimas donde se señalaba el componente de la apariencia como detonante del rechazo. "No es lo mismo vivir como pobre que parecer que se vive a lo pobre" se sentenciaba en una nota de prensa en la que la instalación se criticaba por aludir a las formas de vivir precarias sólo en apariencia, puesto que en el interior se podía constatar lo contrario, al apelar así a una falta de correspondencia entre la imagen y una supuesta idea de verdad. ${ }^{20}$ Sin embargo, los rechazos suscitados no sólo se producían porque lo

I8. Medina, sin considerar la superficie vertical, diría que se ejerció una "privatización del aire". Medina, "Exterior interiorizado", en Sin límites. Arte contemporáneo en la Ciudad de México 20002010 (Ciudad de México: Editorial RM, 20I3), 20.

19. Aunque Schmilchuk no apunta que la realización de su sondeo fuera riguroso, omite dar el número de entrevistados y no se detiene a esclarecer algún tipo de perfil de los entrevistados. Solamente hace notar sus resultados generales. Entre éstos, encontró que 68 por ciento no había visitado nunca el museo y que a 26 por ciento le parecía fea la instalación, mientras que al porcentaje restante le parecía atractiva. Schmilchuk, "Museos y espacio público", M. Museos de México y del Mundo I, núm. 3 (Ier semestre de 2005): 50-55. Por otro lado, sin la intención de hacer una medición estadística, en el catálogo de la exposición se reprodujeron muchas de las notas recibidas en el buzón. En términos generales los comentarios oscilaban desde la felicitación hasta la condena. Entre algunos de los argumentos estaban, por un lado, el asombro por la habilidad técnica y, por el otro, el rechazo por juzgar que se aprovechaba de la pobreza para hacer arte. Ortega, Paracaidista. Av. Revolución I608 bis.

20. Francisco Peña, “Los pobres también venden”, Milenio, 28 de noviembre de 2004, 47. 
marginal no era respetado, sino también porque no permanecía invisible. Para algunos vecinos era precisamente esta apariencia de precariedad la que resultaba molesta.

Así, la falta de marcos de referencia no impedía el establecimiento de una relación subjetiva con una otredad que aparentaba manifestarse como presencia viva. La construcción de subjetividad pasa de manera necesaria por una relación con lo que no es uno, y se deriva, como apunta Suely Rolnik, en respuestas de asombro y temor. ${ }^{2 I}$ Rolnik señala que el otro es entendido desde dos sensibilidades en conflicto: a partir de una cartografía de representaciones y de la presencia viva de su cuerpo. En el proceso de subjetivación, la comprensión del exterior —el mundo y lo otro- se enfrenta a la paradójica falta de correspondencia coherente entre las representaciones y las experiencias corporales, en la que se desata una tensión entre ambas sensibilidades que se canalizan como fuerzas de asombro y temor con las que, finalmente, el sujeto busca movilizar su realidad y sus relaciones con lo exterior. ${ }^{22}$ Ante un acontecimiento tomado como fuente de información, estas fuerzas inclinan la respuesta hacia un lado de la dualidad si/no que regresa al sistema comunicativo, como aceptación/rechazo.

Paracaidista aconteció, entonces, como presentación de un cuerpo en un aparato mediático museo-fachada-casa. El intercambio simbólico que normalmente sucede en una exposición se expande al exterior urbano y marca una diferenciación con éste, al exhibir una combinación entre mostrar/esconder que propició indeterminación. Se muestra el exterior de una casa mientras que el habitante permanece escondido. El aspecto de la casa es la principal pista que se ofrece para develar la función de la construcción y, en consecuencia, la identidad oculta del habitante. La activación de las posibilidades de asombro o temor se detonan al suponer una identidad determinada sobre lo que permanece oculto, que depende de la procedencia del sujeto que hace la observación. La identidad que en un primer momento aparece escondida es la del artista, y se sugiere la de un otro producido por la urbanización excluyente, como presencia viva, como cuerpo que altera la subjetividad de quien observa.

2I. Suely Rolnik, "La vida en venta", Sitios distantes. Crisis urbanas y sintomas domésticos en el arte contemporáneo reciente (San Diego: Installation Gallery, 2005).

22. Rolnik dice que el desequilibrio entre ambas percepciones "genera una crisis de la subjetividad que ejerce presión y suscita sentimientos de asombro y de temor, ocasionando una sensación de vértigo" (Rolnik, "La vida en venta", I46-I53). 
Por último, después de los tres meses de ocupación, el desmontaje de Paracaidista dejó la fachada vacante lo que hizo visible la ausencia del habitante como un cuerpo que ya no está allí, y quedó entonces la pregunta sobre las implicaciones de la disponibilidad en las superficies verticales.

\section{La fachada como terrain vague}

Los espectaculares, las vallas publicitarias y las enormes mantas que cubren edificios se utilizan como soportes para la publicidad exterior. No obstante, si se observa desde una dimensión urbana más amplia, las superficies verticales de la ciudad pueden entenderse como el medio que se hace visible cuando soportan cualquier tipo de decoración y configuración visual. Niklas Luhmann, al analizar el funcionamiento de los medios de comunicación en un sistema social, ubica la distinción entre medio/forma como manera de operar. ${ }^{23} \mathrm{El}$ medio se define por la pluralidad y posibilidad de conexión entre elementos que permanecen laxos. Las formas son visibles en el momento en que fijan una posibilidad de conexión entre determinados elementos, y visibilizan así al propio medio que, de otra manera, no podría observarse. ${ }^{24}$

El mecanismo de las fachadas funciona como una superficie vertical que aloja imágenes; es decir, como un medio que se hace visible cuando soporta formas visuales desde donde se proyectan y reproducen imaginarios. Al alojar reiteradamente imágenes forman parte de un hábitat en el que se exalta la apariencia externa que es impenetrable para el cuerpo. Su artificialidad sugiere

23. Mientras Luhmann está interesado en utilizar este planteamiento para comprender la comunicación de los sistemas sociales (Luhmann, El arte de la sociedad, I7I-I78), Belting busca entender las representaciones del cuerpo y las interacciones en doble dirección entre el cuerpo y la imagen (Belting, Antropología de la imagen). Tanto medio como cuerpo son habitados por la imagen; pero ésta no es sólo una forma independiente, sino que se constituye como parte interrelacionada de una dualidad medio/imagen o cuerpo/imagen, tal y como propone Luhmann entender la dualidad inseparable medio/forma como una forma misma. Belting, al considerar que en la manera de concebir simbólicamente un medio se delata la manera de concebir el cuerpo, encuentra que, ante la expansión tecnológica de los medios de la imagen, el cuerpo ha quedado como una especie de anverso autorrelegado. Habla, por ejemplo, de la metáfora de lo "descorporizado" de la imagen en los medios digitales como reflejo de una nueva manera de experimentar el propio cuerpo (Belting, Antropología de la imagen, I7, II3 y I36).

24. Luhmann, El arte de la sociedad (Ciudad de México: Herder/Universidad Iberoamericana, 2005), I7I-I78. 
la existencia de una profundidad — de una verdad - que parece oculta. ${ }^{25} \mathrm{La}$ exaltación de la apariencia externa e impenetrable en la urbe es planteada por Paul Virilio como la reducción de las cualidades táctiles de la ciudad, en donde se privilegia una visualidad que, al estar vinculada a dispositivos tecnológicos, origina una deslocalización de las referencias espaciales y temporales. ${ }^{26}$

"El gran poder de la fachada", dice Henri Lefebvre, obstaculiza el encuentro con una "verdad del espacio", al suplantarlo por una "lógica de visualización". La fachada, al ser tratada como el elemento principal de la arquitectura, apuntaría a la degradación del espacio, y lo condena a un juego de miradas basado en el ver y ser visto. El problema de la fachada estaría en que fácilmente determina una visualidad que funciona como un rostro capaz de expresar pero, al mismo tiempo, de disimular, de tal manera que produce falsedad en el entorno urbano. ${ }^{27}$

Las modas del mundo neoliberal aprovechan esta capacidad de la imagen en el espacio. Las fachadas se muestran como la cara urbana de la caducidad y la renovación cultural que promueve la aparición de iconos instantáneos para las entidades corporativas que buscan un reconocimiento global. ${ }^{28} \mathrm{La}$ formu-

25. Janet Ward sostiene, retomando a Friedrich Nietzsche, que si las sociedades no giran en torno a verdades constitutivas sino a luchas derivadas de la "voluntad de poder", entonces en el plano urbano también se puede hablar de una "voluntad de superficie" que expresa visualmente al propio poder. Janet Ward, Weimar Surfaces. Urban Visual Culture in Ig20's Germany (Los Ángeles: University of California Press, 200I), 3-37. Nietzsche coloca la verdad como una encubierta condición metafísica construida por las metáforas del lenguaje para sostener posiciones de privilegio. Friedrich Nietzsche, Sobre verdad y mentira en sentido extramoral, trads. Luis M. Valdés y Teresa Orduña (Madrid: Tecnos, I990).

26. Paul Virilio, La ciudad sobreexpuesta, Colección Fotocopioteca, 3 (Cali, Colombia: Fundación Hivos y DOEN, 2009), 5. Recientemente, en 2017, el sistema digital de una valla electrónica ubicada en la Ciudad de México fue infiltrada por un hacker anónimo para sustituir los anuncios publicitarios usuales por videos pornográficos. Esta intromisión deja al descubierto la posibilidad de transmitir cualquier cosa desde cualquier lugar gracias a las herramientas tecnológicas instaladas en la urbe, lo que pone en un nuevo jaque la relación del cuerpo con su espacio y evidencia, al mismo tiempo, una pugna por el control de los medios. "Hackean espectacular en Periférico", El Universal, www.eluniversal.com.mx/articulo/metropoli/cdmx/20I7/03/4/hackean-espectacularen-periferico, consultado el in de febrero de 2018.

27. Para Lefebvre, la desconfianza de la imagen (y del lenguaje) sobre los espacios se debe a que el segundo aparece sólo representado, y por tanto reducido, y se fragmenta así la acción y la experiencia social. Henri Lefebvre, The Production of Space (Oxford: Blackwell, 199I), 99.

28. Los iconos instantáneos de las edificaciones posmodernas, según Hal Foster, han tergiversado las reflexiones críticas del pop art, de las que son herederas, sobre la naturaleza de la apariencia de las cosas, y se han transformado en una afirmación cínica de lo visual. Refiriéndose a la arquitectura de Rem Koolhaas y de Frank Gehry, señala una conjugación de comunicación 
lación de programas arquitectónicos capaces de responder a las necesidades de identidades espaciales específicas apunta a dos flancos producidos por la misma dinámica global del neoliberalismo: por un lado, la homogeneización derivada de sus esquemas de producción y distribución industrial y, por el otro, la derivada del requerimiento de diseñar identidades artificiales de diferenciación ante tal homogeneización. El resultado es el uso de múltiples máscaras con el fin de seducir las percepciones mediante las formas. ${ }^{29}$

Así, las superficies urbanas muestran una relación indisoluble y controlada, entre superficie/profundidad, forma/contenido e ilusión/realidad y alcanzan un potencial comunicativo que se dirige a la proyección de diferencia dentro de patrones de producción similares. Al mismo tiempo, desde las superficies verticales se ejerce una dominación de los imaginarios que se proyectan a escala urbana, resguardados de la intervención de los sujetos, pero dirigidos a su mirada y a la formación de subjetividad. El espacio urbano, al estar colmado de estos mecanismos de visualización, registra una contradicción entre una percepción corporal del espacio y la superposición de imágenes que funcionan como aparatos de subjetivación que refieren a espacios ficticios. El "gran poder" de las superficies urbanas radica en su potencial para constreñir cuerpos, proyectar imaginarios y absorber la profundidad dentro de sí mismas. ${ }^{30}$

Si la experiencia del mundo es accesible sólo a través de los medios, la experiencia de la ciudad se cubre de medios/imágenes que reiteran y fortalecen una separación del cuerpo con el espacio público. Para Rosalyn Deutsche el espacio público es, opuesto al asombro y aceptación a las que está abocada la publicidad, una zona que necesariamente genera conflicto. Esto es que, a diferencia de los imaginarios de coherencia, la dimensión pública del espacio se manifiesta como "la imagen del lugar vacío". $3^{\mathrm{I}}$

y de tecnología en las superficies y formas constructivas que convierten el edificio en una imagen demagógica y, al mismo tiempo, elitista. Véase Hal Foster, "Image-Building", en The Art-Architecture Complex (Brooklyn: Verso, 20II), I-I8.

29. Peter Krieger, "Percepción, conceptualización y determinación de la arquitectura", en Paisajes urbanos. Imagen y memoria (Ciudad de México: Universidad Nacional Autónoma de México-Instituto de Investigaciones Estéticas, 2006), 324.

30. Un control político de las imágenes implica necesariamente un control de los medios que las transmiten. Belting apunta que si bien este control busca tener incidencia en la memoria colectiva, también requiere de una expansión en el espacio público. Hans Belting, "Imagen, medium, cuerpo: un nuevo acercamiento a la iconología”, trad. Óscar Gómez, Cuadernos de Información y Comunicación, núm. 20 (2015): 169.

3I. Rosalyn Deutsche, "Art and Public Space: Questions of Democracy”, Social Text, núm. 33 (I992): 5I. 
Deutsche indica que la existencia de lo público depende de la supresión de la figura de poder y de propiedad; por lo que el vacío generado se sustituye por la interacción social que, lejos de ser una zona de armonía, es conflictiva e inestable. Lo público, contradictoriamente, niega el mismo conflicto que produce su espacio; de tal suerte que si se llena de coherencia produce exclusión. Es la posibilidad de esta contradictoria tensión la que produce el espacio público. La coherencia en la publicidad está detrás de sus atractivas ficciones y en los mecanismos mercadológicos que le dan origen. El arte en el exterior no aspiraría a generar coherencia, sino a revocarla a manera de, en palabras de Rancière, disensos favorecidos por los espacios del arte. ${ }^{32}$ La fachada, si se entiende como cara exterior que puede estar vacía, se confronta al contexto urbano y tiene así la posibilidad de ser una zona propicia para la crítica a los espacios restringidos de representación en la urbe.

El habitar de Paracaidista se dirige contra la propiedad misma de la imagen urbana. Devela la función de la fachada como un terrain vague en tanto que hace visible la vacuidad disponible del medio a través del cuerpo. El medio de la fachada, tomado como lote vertical, es ocupado no por una imagen sino por un cuerpo que, con el habitar, refiere a un espacio. Según Solà-Morales, el terrain vague es la negatividad de un entorno dominado por la razón funcional de la arquitectura y el urbanismo. Se trata de espacios aparentemente abandonados y detenidos en la improductividad, el extrañamiento y la incertidumbre. El sujeto urbano experimenta con estos vacíos una posible salida al control racional del espacio. En el terrain vague observa una incertidumbre como ruta utópica de libertad urbana que desde el arte se puede contraponer a la modernidad homogeneizadora de la ciudad. ${ }^{33}$ Las connotaciones utópicas de la posición del sujeto occidental, desde las que habla Solà-Morales, no pueden mantenerse por mucho tiempo ya que, como señala el investigador brasileño Girnos Elias, la indeterminación del espacio vacío se desvía rápidamente hacia el usufructo por parte de los intereses económicos del capital, o, en el

32. Jacques Rancière, Sobre politicas estéticas, trad. Manuel Arranz (Barcelona: Servei de Publicacions de la Universitat Autònoma de Barcelona, 2005), 69-80.

33. Solà-Morales se refiere a la fotografía de John Davies (1949), David Plowden (1932), Thomas Struth (1954), Jannes Linders, Manolo Laguillo (1953) y Olivio Barbieri (1954) sobre estos espacios residuales. Véase Ignasi de Solà-Morales, “Terrain vague”, en Naturaleza y artificio (Barcelona: Gustavo Gili, 2009). 
contexto de los países periféricos, por la apropiación irregular de la población excluida. ${ }^{34}$

El filósofo y curador Nelson Brissac hace la adaptación del término al contexto latinoamericano al remplazar el sujeto occidental, que sólo percibe el vacío residual producido por la racionalidad urbana, por el sujeto latinoamericano excluido (el indigente, el vendedor ambulante, el pepenador y el habitante de las favelas) que ya vive dentro de los vacíos residuales producidos por las transformaciones urbanas de la globalización. ${ }^{35}$ Mientras que Girnos Elias admira la indeterminación porque allí observa la posibilidad de libertad, Brissac realiza modificaciones forzadas en el espacio para sobrevivir ante su propia condición de indeterminación. El terrain vague queda como espacio fragmentado por la globalización, ocupado por sujetos nómadas que, ante la mirada del sistema artístico y arquitectónico, ofrecen soluciones para plantear estrategias dirigidas hacia una continuidad urbana.

Zamora no es este sujeto nómada; pero su ocupación se ejecuta como si lo fuera. Al hacer esta escenificación, la fachada, caracterizada por su poder visual, se señala como espacio residual. Las superficies urbanas no suelen producir extrańamiento pues siempre están ocupadas por el relevo de lo nuevo y diferente. En Paracaidista este relevo parece detenerse por la superposición de lo fijo y estático que implica una casa. La fachada visualmente productiva se convierte en un terreno improductivo destinado a un cuerpo que permanece oculto dentro de su casa, que comunica con esto cierta incertidumbre y expectativa por la ocupación del no propietario. No se implican de manera directa a sujetos marginales ni se busca representarlos. Tampoco se autosacrifica la posición privilegiada como artista; al contrario, se aprovecha esta condición para realizar la apropiación.

\section{Habitar la fachada}

Sin ser un sujeto marginal —ni para el campo artístico, ni para la zona urbana que ocuparía-, Zamora se apropiaba del aspecto de las viviendas marginales

34. Gabriel Girnos Elias de Souza, "Percepções e intervençóes na metrópole: a experiência do projeto Arte/Cidade em São Paulo (I994-2002)”, tesis de maestría en Arquitectura y Urbanismo (Universidade de São Paulo, São Carlos, 2006), 247-248.

35. Véase Nelson Brissac, "Latin American Megacities: the Urban Formlessness", en The Urban Scene in Latin America (Durham y Londres: Duke University Press, 2009), 233-248. 
al mismo tiempo que lo hacía de la fachada como zona urbana destinada a las apariencias, lo que permitió proyectar su habitar hacia la mirada como ficción. La vivienda construida no sólo contrastaba con el entorno por su aspecto, sino que también se colisionaba visualmente con el condicionamiento perceptivo de encontrar superficies cubiertas con mensajes publicitarios. El habitar la fachada expuso así una conjugación entre un elemento real y otro ilusorio; es decir, entre un cuerpo que habita y una imagen que se proyecta.

Esta dualidad puede comprenderse con el planteamiento de Hans Belting en donde la relación entre cuerpo e imagen opera a través del medio. La manera en que se concibe simbólicamente un medio, dice, delata la forma de concebir el cuerpo. Y de modo inverso, propone entender el cuerpo como medio; es decir, como cuerpo mediatizado capaz de alojar imágenes, así como capaz de proyectarlas. Tanto medio como cuerpo son habitados por la imagen; pero esta última no opera de forma independiente, sino que se constituye como parte interrelacionada de una dualidad medio/imagen o cuerpo/imagen. ${ }^{36}$

La estrategia de Belting de colocar al cuerpo en un estatuto similar a los medios en tanto a la capacidad de alojar imágenes conlleva la problemática del comportamiento visual que el propio cuerpo es capaz de manifestar: "El cuerpo es en sí mismo una imagen desde antes de ser imitado en imágenes." ${ }^{37}$ Así, la comprensión de las imágenes que tratan sobre el cuerpo debiera tener en cuenta que éste ya contiene de antemano una autorrepresentación de sí mismo.

De esta manera Paracaidista, al transponer el habitar como imagen, no se desprende de la imagen del cuerpo, y conserva su manifestación mediante el actuar cotidiano en el espacio; es decir, habitando. La conjugación de los conceptos de cuerpo, medio e imagen opera por medio del habitar y de la superficie vertical de la fachada; se introduce así el elemento adicional del espacio. Si para Belting el "lugar de la imagen" es el cuerpo, ahí se señala el lugar del cuerpo dentro del espacio urbano. Esto implica pensar que si el cuerpo puede ser medial también es espacial, por lo que se requiere tomar en cuenta que la visualidad que ahí se está desplegando va de la mano con el desenvolvimiento cotidiano del cuerpo, es decir, con su habitar.

Por otra parte, para Lefebvre el habitar actúa como una fuerza conflictiva de apropiación del espacio. Para el individuo, dice,

36. Belting, Antropología de la imagen.

37. Belting, Antropología de la imagen, II2. 
apropiarse no es tener en propiedad, sino hacer su obra, modelarla, formarla, poner el sello propio [...] es también hacer frente a los constreńimientos, es decir, es el lugar del conflicto, a menudo agudo entre los constreñimientos y las fuerzas de apropiación [...] el conflicto entre apropiación y constreńimientos es perpetuo a todos los niveles, y los interesados los resuelven en otro plano, el de la imaginación, de lo imaginario. ${ }^{38}$

Ahí encontraremos que el habitar, como fuerza tanto rutinaria como creativa, se confronta a un hábitat colmado de imágenes en un espacio normativo y excluyente. Así, la apropiación de un emplazamiento privilegiado de Paracaidista, la referencia deslocalizada a las construcciones periféricas, el habitar de Zamora y el encuentro sorpresivo de la instalación en medio del desplazamiento cotidiano de los receptores casuales se conformaron como las aristas desde donde se establecieron vínculos con la crisis de la dimensión pública del espacio urbano.

En la Ciudad de México, al igual que en otras urbes globales, se vive un proceso de homogeneización neoliberal en donde la disociación entre el espacio jurídicamente público y las prácticas de la vida cotidiana se encaminan a la superposición de la dimensión privada sobre la pública. La multiplicación y el crecimiento de plazas comerciales, el cierre de calles por residentes, las apropiaciones de espacios por parte de comerciantes informales, la gentrificación, la especulación inmobiliaria y la construcción de enclaves autosuficientes como autosegregación residencial son fenómenos que han configurado el espacio de la ciudad, que zonifican y delimitan el comportamiento de los habitantes. ${ }^{39}$ En este sentido, las imágenes aparecen por medio de la presencia desbordante e irregular tanto de soportes publicitarios tradicionales como de grandes pantallas electrónicas que forman parte de esta crisis del espacio público y configuran un hábitat dirigido a la mirada que excluye el cuerpo.

Quien habitó la fachada fue, entonces, un artista que, sin asumir un comportamiento de supervivencia como el de los habitantes de las zonas marginales, generó un acontecimiento mediante la presencia de su cuerpo que volvía a

38. Henri Lefebvre, De lo rural a lo urbano, trad. Javier González-Pueyo (Barcelona: Anthropos, 1978), 210.

39. Sobre el registro de estos fenómenos urbanos de la Ciudad de México a principios del siglo xxi, véase Emilio Duhau y Ángela Giglia, "El espacio público en la Ciudad de México. De las teorías a las prácticas", en Los grandes problemas de México. Desarrollo urbano y regional (Ciudad de México: El Colegio de México, 2010), 389-447. 
introducirse al mundo de las imágenes. La comunicación publicitaria apropió y adaptó esta relación posteriormente para generar imágenes seductoras que, a pesar de tomar la presencia de un cuerpo como base, se encaminaban a la exclusión del cuerpo de los receptores.

\section{El cuerpo como representación de si mismo}

El cuerpo, con las cualidades de cuerpo/imagen y cuerpo/medio, parece estar condicionado a las tensiones similares que se observan en las superficies urbanas. La posibilidad de alcanzar una profundidad oculta queda acotada por las proyecciones que suceden exteriormente. Una "voluntad de superficie", como menciona Janet Ward, es subjetivada a manera de estados mentales que reafirman y reproducen las soberanías de poderes políticos y económicos. $4^{\circ}$ Actualmente, es en las redes digitales donde se puede percibir de manera clara

40. Sobre la "voluntad de superficie" véase la nota 23. La complejidad de la surface culture ha desatado diferentes posiciones. Según Ward, para Walter Benjamin, George Simmel y Sigfried Kracauer existe un potencial de liberación social gestado aun dentro de la propia fascinación que suscita, mientras que, desde una nostalgia por lo real, Guy Debord condena los imaginarios del espectáculo, critica los medios masivos y la estética de las mercancías. Al seguir a Debord, con las nociones de simulación e hiperrealidad de Baudrillard, el significante y significado se diluyen y niegan la posibilidad de una profundidad en la que se encontraría la realidad (Ward, Weimar Surfaces, 3-37). Por otro lado, una relación entre cuerpo y superficies urbanas puede seguirse mediante las reflexiones sobre el grafiti del propio Baudrillard. La estrategia de visualización del grafiti está basada en la superposición y el desbordamiento y rechaza así sus soportes: "la superposición equivale a la abolición del soporte como plan, así como el desbordamiento equivale a su abolición como marco". Jean Baudrillard, "El orden de los simulacros", en El intercambio simbólico y la muerte, trad. Carmen Rada (Caracas: Monte Ávila, I980), 30. Baudrillard desconfía de los proyectos artísticos que buscan dialogar con la arquitectura y el urbanismo porque parten de un respeto de los soportes y los lenguajes que reduce la posibilidad de una confrontación radical. Asimismo valora el grafiti por su indiferencia a las superficies, pero sobre todo, lo idealiza al considerarlo como diferencia incodificable, como no-signos que operan únicamente como significantes sin significado. No obstante, es Sonja Neef quien recupera la posición del cuerpo como medio generador de la imagen. La imagen del grafiti es un gesto táctil que refiere al movimiento ejecutado rápidamente. La diferencia simbólica que se genera no es la de un no-signo inmerso en un entorno de signos, como lo plantea Baudrillard, sino la de un acto del cuerpo que se extingue en el momento en que se ejecuta, se reactiva mediante la repetición, y deja huellas en el contexto urbano. Lo que se exhibe entonces es tanto un sujeto cultural como la imagen que produce. Sonja Neef, "Killing Kool: The Graffiti Museum”, Art History, núm. 3 (junio, 2007), 422. Neef dirige la atención hacia las acciones del cuerpo como salida a las imposiciones visuales, y regresa así a 
estas tensiones de los cuerpos. En éstas el sujeto moderno compite con otros sujetos mediante la proyección de una imagen atractiva para asegurarse mayor visibilidad y, por tanto, mayor influencia social: "El sujeto moderno ahora tiene una nueva obligación: la obligación de auto-diseñar una presentación estética de sí mismo como sujeto ético". ${ }^{41}$ Con este señalamiento, Boris Groys sugiere que el aspecto ético adquiere importancia porque, en principio, existe una coerción social en la que el sujeto debe mostrarse apegado a una verdad interior. Esta verdad, contradictoriamente, debe manifestarse mediante apariencias: "El cuerpo toma la forma del alma. El alma se vuelve el cuerpo." ${ }^{22} \mathrm{En}$ el cuerpo, para Groys, se experimenta como el colapso de la distinción superficie/profundidad, ya que, en tanto cuerpo —el lugar de la imagen para Belting - debe proyectar como obligación ética su alma — la verdad del sujeto.

La proyección de la cualidad del cuerpo/imagen como punto de partida para generar más imágenes se puede observar en la campaña publicitaria de 20I3 llamada \#ScribeBillboard, la cual promocionaba la marca de cuadernos y libretas Scribe con los objetivos de actualizar su presencia visual y atraer el interés de públicos jóvenes. ${ }^{43}$ La campaña consistió en la contratación de una joven artista, Cecilia Beaven, para que habitara detrás de un anuncio espectacular, colocado en la zona comercial y elitista de Polanco de la Ciudad de México, el cual pintaría durante diez días con motivos que el público sugería por Twitter. ${ }^{44}$

una tactilidad que Paul Virilio consideraría perdida. El cuerpo aparecería como una obstrucción visual al mostrar sus propios actos sobre cualquier superficie de la que se carece propiedad.

4I. Boris Groys, "La obligación de autodiseñarse", en Antología, trad. Saúl Villa (Ciudad de México: сосом Press, 2013), 59.

42. Groys, "La obligación de autodiseńarse", 6r.

43. La marca Scribe surgió en 1963 dentro de la compañía Kimberly Clark México. Después, en 2006, la empresa Grupo Papelero Scribe, S.A. de C.V., se desvinculó de Kimberly Clark México y se quedó con la marca Scribe. Más recientemente, en 2013, la empresa Bio Pappel, S.A. de C.V., compró Scribe. Para esta adquisición se realizó un cambio de logotipo de la marca acompañado por la campaña publicitaria \#ScribeBillboard como reflejo visual del último movimiento empresarial y como estrategia para atraer a públicos jóvenes. "Company Overview of Bio Pappel Scribe, S.A. de C.V.", Bloomberg, consultado el 26 de junio de 2016 , en www.bloomberg.com/Research/stocks/ private/snapshot.asp?privcapId=34074068. La agencia publicitaria La Doble Vida que diseñó la campańa obtuvo un reconocimiento en la $60^{a}$ edición del Festival Internacional de Creatividad Cannes Lions del mismo 2013 en la categoría Outdoors.

44. El espectacular se instaló en la azotea de la boutique High Life, ubicada en la esquina de la avenida Presidente Masaryk y Alejandro Dumas. El interior de la habitación tenía un aspecto sencillo y refinado. No había elementos de precariedad y escasez. La habitación contaba con todos los servicios y mobiliario suficiente para proporcionar confort (cama, cocineta, baño, ropero, ventanas y mesa de 
Con un intenso trabajo de redes digitales y de relaciones públicas, la campaña publicitaria buscaba difundirse como un acontecimiento relevante para funcionar "a un cierto nivel de realidad" ${ }^{45} \mathrm{El}$ \#ScribeBillboard se comunicó como noticia, como publicidad y como entretenimiento; ${ }^{6}$ pero su sustento con la realidad estribó en el habitar la superficie urbana de un cuerpo que, al hacerlo, se transformaba en imagen. El habitar, convertido en imagen, proyectaba la capacidad de un cuerpo para producir, a su vez, imagen (su identidad) y espacio (su habitar) simultáneamente (fig. 3). ${ }^{47}$

En videoblogs, Beaven describía día con día sus experiencias cotidianas y anunciaba las actividades por venir. Beaven, como enviada dentro de una exhibición-espectáculo-performance representaba a Scribe, pero como condición de representarse a sí misma. La ficción del habitante marginal que se desplegaba en Paracaidista cedía el lugar a la identidad de una artista que no intentaría parecer ser otra cosa. Se buscaba mantener el perfil de Beaven como artista (como cuerpo disciplinado), a la vez que se enfatizaba una espontaneidad inmersa en una supuesta vida cotidiana. No recibió algún tipo de entrenamiento previo para adecuarse a las dinámicas del espectáculo; sólo debió habitar la casa y desarrollar el trabajo comisionado. ${ }^{48}$

trabajo). A pesar de ser un espacio habitable pequeño, se le dotaba de exclusividad y refinamiento al estar en Polanco. La avenida Masaryk se caracteriza por sus boutiques de lujo y restaurantes, pero en la zona también se encuentran embajadas, galerías, oficinas empresariales, escuelas privadas, centros comerciales, residencias y departamentos para la clase alta. En la galería Patricia Conde, ubicada también en Polanco, se realizó una rueda de prensa inaugural que daba inicio a la campańa.

45. Con esta frase Klaus Biesenbach intenta explicar el funcionamiento del arte producido en la Ciudad de México en donde observa que las piezas artísticas no podían suceder de manera aislada, sino al contrario, tenían que estar interactuando con un contexto social extraartístico para poder funcionar. Entre las piezas de la muestra organizada por Biesenbach para el P.S.I de Nueva York se encuentra el Obelisco Roto y las caminatas de Alÿs. Klaus Biesenbach, Cuauhtémoc Medina y Patricia Martín, Mexico City: An Exhibition about the Exchanges Rates of Bodies and Values (Long Island, Nueva York: мома, P.S.I, Contemporary Art Center, 2002), 284.

46. Para Luhmann, los medios de comunicación procesan la información únicamente bajo tres modalidades: como noticia (relevo de acontecimientos con corta vigencia temporal), como publicidad (donde se enfatiza la novedad vinculada primordialmente a las mercancías), y como entretenimiento (basada en la revelación de un elemento que permanece en inicio oculto). Niklas Luhmann, La sociedad de la sociedad (Ciudad de México: Universidad Iberoamericana, 2006), 864.

47. Véase www.ceciliabeaven.com/scribe-billboard/

48. A Beaven se le seleccionó por su jovialidad y por el tipo de trabajo visual naif que había desempeńado previamente. El proyecto le fue planteado inicialmente como la elaboración de un mural publicitario. Después de unos meses, la agencia publicitaria le presentó el proyecto 
El \#Scribebillboard, que se autopresentaba como un proyecto artístico (al enfatizar la profesión de Beaven el "inaugurarse" en la sala de una galería) se acerca a una manera de realizar y ejecutar la imagen que hace del habitar de Beaven el cuerpo como medio vivo. No obstante, ahí lo performático del cuerpo se encuentra ligado a la noción mercadológica de la activación de marca; es decir "de traer a la vida el espíritu de las marcas" con el objetivo de "motivar a una participación positiva de la gente", por medio de la "la integración de los medios de comunicación disponibles en una plataforma creativa". ${ }^{49}$ Por tanto, la marca requiere de cuerpos (medios) donde pueda encarnarse para interactuar con los receptores. Si el habitar es una manera de apropiación del espacio que está en constante conflicto con los constreñimientos de un hábitat modelado y regulado, el habitar de Beaven queda atado a un discurso mercadológico del cual no puede escapar y que, a pesar de mostrarse como ella misma, encarna con su cuerpo la nueva imagen de Scribe. Se buscaba proyectar la ficción de una subjetividad coherente y excepcional para ser considerada ante el receptor como posibilidad de identificación. Si para Belting la presentación del cuerpo

definitivo para convencerla de participar. Cecilia Beaven, en entrevista personal del 2I de abril de 20I5. La agencia encontró con el imaginario de un habitar vinculado a las posibilidades de las redes digitales una estrategia que haría más compleja —y tecnológicamente más actual— la realización de la campańa que la sola elaboración de un mural. Se estableció una intermedialidad en donde cada componente mediático (el mural-espectacular, el cuerpo de Beaven, la casa-habitación y Twitter) se referenciaban entre sí y donde se buscaba que las imágenes generadas se desplazaran entre éstos. La imagen "mural" del espectacular que quedó en propiedad de Scribe ha sido reproducido en diferentes soportes comercializables (portadas de cuadernos, ediciones de libretas especiales, por ejemplo). Durante los diez días de duración, los avances graduales de esta imagen se reprodujeron día a día al colocarse en otros espectaculares ubicados en diferentes ciudades del país. Además de que la composición terminada se reprodujo en diversas mercancías, sirvió como tema para nuevos eventos, como concursos de dibujo para nińos promovidos en escuelas. De esta manera Scribe contaba ahora con una composición bidimensional que remitía tras de sí una supuesta participación social y el habitar de Beaven. Ya anteriormente, José Luis Cuevas había planteado una relación mediática entre mural, superficie comercial y arte-evento. Con su Mural efímero (1967), montado como anuncio espectacular en la Zona Rosa de la Ciudad de México, buscaba ironizar — pero al mismo tiempo citando— la solemnidad del muralismo mediante un soporte publicitario banal. Cuevas procuró mantener el reconocimiento total de autoría que, al convocar a la prensa para presentar el resultado, generó un acontecimiento que servía como promoción personal por medio de comunicaciones noticiosas. Véase José Luis Cuevas "El mural efímero", Letras Libres, consultado el II de febrero de 20I8, en www.letraslibres.com/mexico/ revista/convivio/el-mural-efimero.

49. “QQué es una activación de marca? 3 definiciones”, Merca 2.o, consultado el II de febrero de 20I8, en http://www.merca20.com/que-es-una-activacion-de-marca-3-definiciones/. 
como representación de sí mismo radica en la carga de significados que previamente lo habitan, en el \#ScribeBillboard el cuerpo como imagen se convertía en imagen del medio. ${ }^{50}$

El \#ScribeBillboard, al ubicarse encima de un edificio, era inaccesible para el cuerpo de los transeúntes. La altura hacía invisible a todo el equipo de producción que se encontraba instalado en la azotea; o dicho de otro modo, debajo de la estructura de la casa-espectacular. La exterioridad de la superficie apelaba a la mirada del público, excluyendo su cuerpo, mientras que el espacio interior estaba condicionado por la mirada de la cámara que, por medio de la edición y de los encuadres, generaba la ficción de ser habitado únicamente por la artista. ${ }^{\text {II }}$

En Paracaidista, la altura producía un efecto similar de inaccesibilidad del cuerpo. El público transeúnte sólo podía imaginarse cosas. No obstante, el habitar de Zamora, al estar sujeto a la mirada del público que solicitaba una visita, desplegaba también una representación de sí mismo: como artista dentro de un espacio temporalmente cotidiano. Adentro, no tenía que ser otra cosa, aunque debía asumir un papel específico por el contexto de la institución artística que lo enmarcaba. Mientras el \#ScribeBillboard producía tan sólo asombro. No exis-

50. Belting resume la noción del cuerpo como un medio vivo con la frase "Bodies perform images (of themselves or even against themselves) as much as they perceive outside images." Belting, "Image, Medium, Body: A New Approach to Iconology", Critical Inquiry 3I, núm. 2 (invierno, 2005), 3II. El verbo to perform, en la traducción de Óscar Gómez para la revista Cuadernos de Información y Comunicación del artículo de Belting, se lee con la frase "Los cuerpos realizan y ejecutan imágenes". Como dice Diana Taylor desde los estudios del performance, el verbo to perform —y el sustantivo performance - contiene una complejidad en su traducción al español debido a sus múltiples capas de significado empleados dentro de una amplia gama de contextos que pueden ser hasta contradictorios. Para destacar su aspecto adjetivado relacionado con la acción, teatralidad y el espectáculo (pero sin llegar a ser sinónimo de éstos) propone usar la palabra performático en vez de performatividad, de manera que se pueda hacer propiamente una distinción con los efectos del discurso analizados por John L. Austin, Jacques Derrida y Judith Butler. Diana Taylor, "Introducción. Performance, teoría y práctica”, en Ricardo Rubio, Alcira Bixio, Ma. Antonieta Cancino y Silvia Peláez, Estudios avanzados de performance, trads. Diana Taylor y Macela Fuentes (Ciudad de México: Fondo de Cultura Económica, 20II), 24-28. Así, encuentro que la frase de Belting, en la que subraya el verbo to perform para contrastarla con to perceive, apunta a que la realización y ejecución de la imagen con el cuerpo implica también pensar una actividad performática del cuerpo con el espacio urbano, el cual es tomado como escenario de estas realizaciones y ejecuciones.

5I. El equipo de producción y Beaven trabajaban con horarios establecidos. Sólo al terminar la jornada laboral, los trabajadores se retiraban y Beaven podía disponer del espacio como si fuera su espacio privado. 


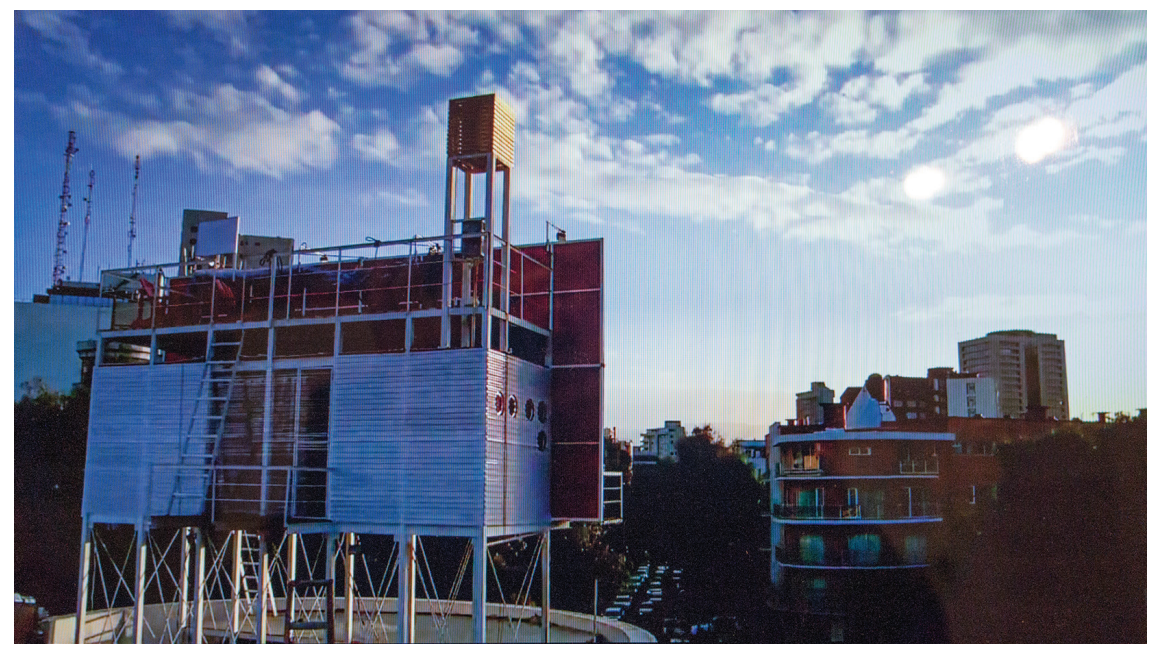

3a) \#ScribeBillboard, Ciudad de México, 2013. Vista posterior de la casaespectacular. Agencia la Doble Vida, fotograma; b) \#ScribeBillboard, Ciudad de México, 20I3. Vista exterior durante el proceso de realización de la pintura de Cecilia Beaven. Foto: Paola León.

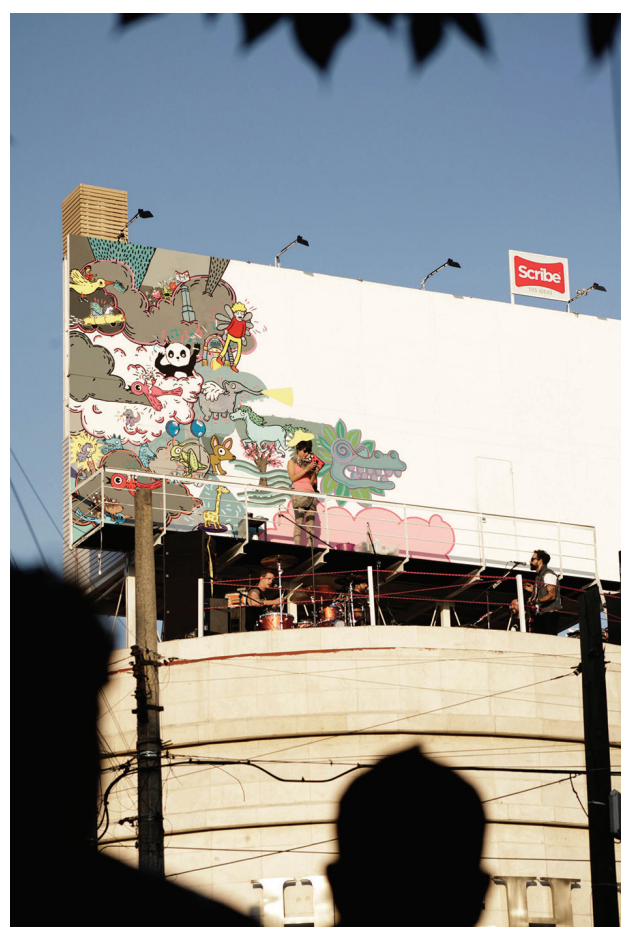




\section{EDUARDO MALDONADO VILLALOBOS}

tía un elemento que desestabilizara la percepción, como la referencia que hacía Paracaidista a un otro marginal. La figura del otro proveniente de la dimensión pública se reducía a una participación anónima y bajo competencia. El público participante deseaba ser elegido por la mirada de quien había fascinado previamente su mirada. Con el envío de propuestas que pretendían ser atractivas, los participantes se ajustaban a la lógica del juego y se impulsaba la vida social de la campaña. Así se animaba una ficción en la que Beaven se asumía también como representante del público para intervenir sobre la urbe y para dejar una marca visible según sus deseos. Pero Beaven y el equipo de producción de la campaña sólo seleccionaban las ideas y realizaban una extracción de sentido para orientar los motivos de la composición comercial, sin mayor correspondencia con su origen.

"No se cree en lo que se dice, pero se obra como si se creyese" señala Baudrillard para denunciar la postura del público ante las ficciones de la publicidad.52 No obstante, el sistema publicitario ha requerido fomentar esta creencia y producir sustentos con la realidad. El habitar de Beaven es una encarnación de las fantasías publicitarias para otorgarles realidad y es un mecanismo para reducir un posible exceso de ilusión que produzca desconfianza. Belting afirma que "Si bien las imágenes están supeditadas a la ley de las apariencias, afirman su ser en el mundo de los cuerpos a través del medio en el que encuentran su lugar en el espacio social". ${ }^{53} \mathrm{El}$ medio utilizado para las apariencias es el propio cuerpo.

El habitar de Beaven es una encarnación de las fantasías publicitarias de la misma manera que el habitar de Zamora es una encarnación de las tensiones artísticas. Ahí, el sistema publicitario y el sistema del arte como generadores de ficción que buscan producir realidad (la acción del consumo para uno, la reflexión crítica y estética para el otro) invierten sus términos de operación al tomar la ciudad y el cuerpo como mecanismos para disolver momentáneamente sus marcos de interpretación usuales para intentar generar otros distintos. La indeterminación y la revelación como parte de una exhibición del habitar relativizan la virtualidad de los imaginarios, buscan fundirse con la realidad de la vida social. Tanto en el \#ScribeBillboard, como en Paracaidista, la referencia a un otro (los integrantes del público participante o el habitante marginal) opera sólo en tanto extracción de sentido para configurar el aspecto de la ficción.

52. Baudrillard, El sistema de los objetos, trad. Francisco González Aramburu (Ciudad de México: Siglo XXI, 2007), I88.

53. Belting, Antropología de la imagen, 63. 


\section{Llenado de vacio}

"Si pueden vivir en un billboard, no se lo pierdan", recomendó Beaven en un video promocional de la campaña del \#ScribeBillboard. ¿Quién puede vivir en un billboard? es la pregunta que surge ante la recomendación. Se puede intentar responder diciendo que lo puede hacer cualquiera que encarne una voluntad de superficie; es decir, que esté dispuesto a asumir su cuerpo como imagen y a aceptar las tensiones entre realidad y ficción que ello implica. Esto no significa escapar de los mecanismos de poder puesto que la interiorización de esta voluntad de superficie está cooptada por el capitalismo cultural a manera de competencia de imaginarios y mantiene colmado e inaccesible el vacío, los terrain vagues, de las superficies urbanas. Esto obligaría a la generación de otros vacíos similares como recovecos por ocupar. El cuerpo, como fuerza visual, seguiría funcionando como un mecanismo más dentro de una maquinaria más amplia; pero tendría la posibilidad de seńalar el nuevo espacio disponible encontrado en la urbe y colapsarlo con las propiedades visuales del cuerpo.

Los mecanismos de poder y de la economía eliminan la visibilidad de la incertidumbre y de la indeterminación en los espacios urbanos; los llenan de ilusiones como coherencias mediante la imposición de dispositivos de control y como relevo permanente de imaginarios. Las pausas en estos relevos, como momentos de vacío (como en espera de un nuevo ocupante), no dejan de mantener su presencia simbólica como superficies que obstaculizan la mirada, restringen la circulación de los cuerpos y detonan interpretaciones simbólicas; y no se escapan de estar condicionadas por la posesión. Su disponibilidad responde a una parcelación/repartición que regula las maneras de ocupación.

El poder político y económico se expresa con la imposición de emblemas y el control del espacio al llenarlo de coherencia para evitar las incertidumbres del vacío. Las grandes plazas y avenidas se abren como control territorial de la urbe. La ocupación de los cuerpos por medio de las marchas busca contravenir el control del vacío. La presencia múltiple de cuerpos sólo puede manifestarse bajo el anonimato; pero detonan su fuerza visual. El cuerpo se vuelve imagen que tiene el potencial no sólo de llenar los vacíos urbanos, sino también de perturbar la dominación visual de los medios de comunicación lo que implica una especie de conciencia del cuerpo como imagen, pero también como productor de espacio.

Paracaidista se desmontó después de tres meses de duración. Con el retiro de la casa y de su habitante se produjo un vacío que con anterioridad no era visible: la posibilidad de ocupación física de una superficie urbana. Paracaidista 
transformó la fachada, usualmente empleada como medio para la imagen, en vacío para la ocupación del cuerpo. El cuerpo se convirtió en imagen al habitar su propio medio: el aparato museo-fachada-casa. Si bien el cuerpo es un medio que aloja y proyecta imágenes, también puede ser la antípoda de los propios medios que inventa para la transmisión de imágenes. El medio exige al cuerpo ciertas conductas y no otras, por lo cual se trata de una relación no simétrica.

La fuerza visual de un individuo en los medios de comunicación y en la ciudad es más bien limitada. En los espacios públicos, la vigilancia y la restricción de accesos están encaminados a la eliminación del anonimato. En contraparte, la realización de un acto performático, ya sea político, económico o artístico, singulariza al cuerpo y señala una identidad que puede adquirir visibilidad. Paracaidista singularizaba la presencia de un cuerpo mediante la producción de un medio propio y de la ficción del sujeto marginal derivada de una extracción de sentido.

El arte lanza su mirada hacia fuera, se apropia y adapta las manifestaciones y problemáticas provenientes de otros sistemas a sus propias reflexiones. La extracción de sentido es una operación de observación y apropiación. Este mecanismo ha caracterizado el arte en exteriores como una estrategia que le permite diferenciarse, a la vez que le permite realizar formulaciones para reinsertarse en el contexto observado. Pero ante la saturación de manifestaciones visuales de la urbe, y el uso de nuevas estrategias y tecnologías desde el poder y desde los espectáculos, el arte se esfuerza por absorber la creatividad y la problemática de su entorno para producir nuevos vacíos que pueda ocupar con cimientos que impidan actuar como ligeros montajes que desembocan en desilusión. \$ 